\title{
Insulin increases $17 \beta$-estradiol production by the dominant follicle of the first postpartum follicle wave in dairy cows
}

\author{
S T Butler, S H Pelton and W R Butler \\ Department of Animal Science, Cornell University, Ithaca, NY 14853, USA \\ Correspondence should be addressed to W R Butler; Email: wrb2@cornell.edu
}

\begin{abstract}
Prolonged anovulation following parturition has a negative impact on fertility in dairy cows. Insulin plays an important role in ovarian function in many species, and is profoundly depressed in dairy cows during early lactation. We hypothesized that hypoinsulinemia during early lactation represents a key indicator of nutritional status, resulting in delayed ovulation. Holstein cows $(n=10)$ were subjected to either a hyperinsulinemic-euglycemic clamp (INS) or saline infusion (CTL) for $96 \mathrm{~h}$, beginning on day 10 after parturition during the first postpartum follicular wave. Insulin was infused continuously $(0.3 \mu \mathrm{g} / \mathrm{kg}$ body weight per $h$ ) via a jugular catheter, and euglycemia was maintained by infusion of glucose. Circulating insulin concentrations were elevated 2.6-fold in INS cows compared with CTL cows $(0.73 \pm 0.026$ vs $0.28 \pm 0.026 \mathrm{ng} / \mathrm{ml} ; P<0.001)$. Insulin treatment did not affect $(P>0.05)$ luteinizing hormone (LH) pulse frequency, pulse amplitude or mean circulating LH. Circulating estradiol was elevated in INS cows $(P<0.01)$ and circulating testosterone also tended to be higher. The ratio of testosterone to estradiol was not different between treatments for the initial $30 \mathrm{~h}$ of infusion, but was significantly reduced thereafter in response to insulin $(\boldsymbol{P}<\mathbf{0 . 0 1})$, suggesting that hyperinsulinemia increased follicular aromatase activity. Insulin treatment also resulted in reduced circulating nonesterified fatty acids, and increased circulating total and free insulin-like growth factor-I concentrations. Insulin infusion increased estradiol secretion by the dominant follicle of the first postpartum follicular wave in dairy cows, and this effect appears not to be mediated through changes in pulsatile LH release.

Reproduction (2004) 127 537-545
\end{abstract}

\section{Introduction}

Intense genetic selection of dairy cattle for increased milk production has been associated with a reciprocal change in reproductive efficiency (Butler \& Smith 1989, Darwash et al. 1999). It is generally accepted that energy balance (calories consumed minus calories expended), rather than intake of any specific class of nutrient (carbohydrate, lipid or protein), is the main regulator of reproductive status (Butler \& Smith 1989, I'Anson et al. 1991). During early lactation, the energetic cost of rising milk production is greater than the energy consumed, resulting in a prolonged period of negative energy balance (NEB). Thus, in terms of body tissue mobilization, early lactation is analogous to severe undernutrition; it is typical for lactating cows to lose $30-40 \%$ of their initial lipid reserves at parturition (Chilliard et al. 2000). There are many changes in the metabolic and endocrine milieu associated with NEB in the periparturient cow that are implicated in the reduced reproductive performance. Pulsatile release of luteinizing hormone $(\mathrm{LH})$ is diminished; circulating levels of insulin, insulin-like growth factor-I (IGF-I) and leptin and glucose are depressed; and nonesterified fatty acids (NEFA), $\beta$-hydroxybutyrate and growth hormone are elevated (for recent reviews, see Butler 2003, Diskin et al. 2003).

Insulin, which is secreted from the pancreatic $\beta$-cells, plays a central role in the metabolism of the body. Insulin is also well recognized as a signal of energy status to the central nervous system (Ingvartsen \& Andersen 2000, Schwartz et al. 2000). Insulin receptors have been localized in the arcuate nucleus and medial basal hypothalamus (regions of the brain containing gonadotropinreleasing hormone $(\mathrm{GnRH})$ neurons) of the rat (van Houten et al. 1979). In vitro culture studies of hypothalamic explants indicate that insulin can stimulate $\mathrm{GnRH}$ release (Arias et al. 1992), and studies in diabetic rats and sheep indicate an absolute requirement for insulin for normal LH pulsatility and induction of the LH surge (Kirchick et al. 1982, Bucholtz et al. 2000). Furthermore, dietary treatments known to increase gonadotropin release in sheep are associated with increased circulating and cerebrospinal fluid concentrations of insulin (Miller et al. 1998). At the level of the ovary, insulin receptors are widely distributed throughout all ovarian compartments, 
including granulosa, thecal and stromal tissues (Poretsky \& Kalin 1987). In vitro studies have shown that insulin directly stimulates both mitosis and steroid production of cultured bovine granulosa (Gutierrez et al. 1997), theca (Stewart et al. 1995) and luteal cells (Mamluk et al. 1999).

Early resumption of ovulatory estrous cycles following parturition is associated with improved fertility in dairy cows (Darwash et al. 1997, Westwood et al. 2002, Butler 2003). Previous reports have indicated that follicular activity during the early postpartum period is characterized by a large incidence of dominant follicles that appear to grow at a normal rate, but have compromised estradiol synthetic capacity (Beam \& Butler 1997, 1998). This results in a disproportionate percentage of follicles undergoing atresia $(>40 \%)$ rather than ovulation (Beam \& Butler 1999). It has been posited that the capacity of the dominant follicle to produce estradiol, stimulate an LH surge, and ovulate is dependent on (i) the frequency of $\mathrm{LH}$ pulses during follicular growth and (ii) the circulating concentrations of insulin and IGF-I (Beam \& Butler 1999), both of which act synergistically with gonadotropins to stimulate steroidogenesis. Gong et al. (2002) recently demonstrated that dietary-induced increases in circulating insulin resulted in improved reproductive performance in dairy cows. Collectively, these observations led us to hypothesize that the depressed circulating levels of insulin observed in the early lactation period represent an important metabolic signal linking nutritional status to the reproductive axis in dairy cows. To test this hypothesis, dairy cows were subjected to either a hyperinsulinemiceuglycemic clamp or a saline infusion for 4 days during the first postpartum follicular wave. The results of the study indicate that elevated circulating insulin stimulates ovarian steroidogenesis independently of any apparent effect on pulsatile LH release.

\section{Materials and Methods}

\section{Animals and treatment}

All experimental procedures were approved by the Cornell University Institutional Animal Care and Use Committee. The experimental procedures were similar to those previously described (Butler et al. 2003). Ten mature lactating Holstein cows (of $620 \pm 20 \mathrm{~kg}$ body weight ( \pm S.E.M.) at 10 days postpartum) had ad libitum access to a total mixed ration (1.63 Mcal $\mathrm{NE}_{1} / \mathrm{kg}$ ) formulated for nutritional support of early lactation cows. The average parity of the cows was 3 (range 2-6). Feed was offered every $2 \mathrm{~h}$ to minimize postprandial variations in nutrient supply, and water was freely available at all times. Daily samples of the feed offered were composited on a monthly basis for nutrient analysis (Dairy One Cooperative, Ithaca, NY, USA). Feed refusals were weighed and discarded at noon each day. Cows were milked at $0600 \mathrm{~h}$ and $1800 \mathrm{~h}$ daily, milk yield was determined, and milk samples were collected for compositional analysis twice weekly (Dairy One Cooperative).

On day 8 postpartum, cows were randomly assigned to either a hyperinsulinemic-euglycemic clamp (INS (insulin)) or saline infusion (CTL (control)) treatment $(n=$ 5/treatment). For both treatments, three indwelling jugular catheters were inserted (Tygon Microbore Tubing, Norton Performance Plastic, Akron, OH, USA); two catheters on one side were used for infusion of solutions (insulin and glucose or saline), and the catheter on the contralateral side was used to collect blood samples. Baseline measurements (four blood samples/day) were taken on days 8 and 9, and the treatments were imposed for a 96-h period, starting at $1500 \mathrm{~h}$ on day 10 and finishing at $1500 \mathrm{~h}$ on day 14 . As a prophylactic measure, animals were treated with penicillin $G$ procaine $\left(9 \times 10^{6}\right.$ units/day; Butler Company, Columbus, OH, USA). For the INS group, the target glycemia for each cow $( \pm 10 \%)$ was based on the average blood-glucose concentration for that individual cow determined during the baseline measurements. The insulin infusate was prepared for each cow by dissolving purified bovine pancreatic insulin (I-5500, lot 109H0967, 28.3 USP units/mg; Sigma) in $0.01 \mathrm{M} \mathrm{HCl}$, followed by dilution with sterile saline-containing plasma $(1.25 \%)$ from that cow. The insulin solution prepared for each cow was calculated to provide an infusion rate of $0.3 \mu \mathrm{g} / \mathrm{kg}$ body weight per $h$, and was infused via a syringe pump (model SE 400; Vial Medical, Grenoble, France). During the insulin infusion, euglycemia was maintained by infusion of glucose $(50 \% \mathrm{w} / \mathrm{v}$ dextrose solution; Butler Company) from sterile bottles at variable rates with a peristaltic pump (Micro/Macro Plum XL; Abbott Laboratories, Morgan Hills, CA, USA). Blood samples were collected hourly during the 96-h infusion period. Blood-glucose concentrations were determined immediately (SureStep Blood Glucose Monitoring System; Lifescan, Milpitas, CA, USA), and the infusion rate of glucose was adjusted if necessary. For CTL animals, sterile saline was infused at a rate of $100 \mathrm{ml} / \mathrm{h}$ for $96 \mathrm{~h}$, and blood glucose was measured every $4 \mathrm{~h}$.

Blood samples were collected at 10-min intervals for $8 \mathrm{~h}$ immediately prior to commencement (BASE) and termination of infusions (END). In addition, 10-min blood samples were collected from INS cows for a further $8 \mathrm{~h}$ immediately following the commencement of the insulin infusion (START).

Ovarian follicular activity was examined daily in all cows from day 8 postpartum until the end of the first follicular wave by linear array ultrasonography with a 7.5 MHz transrectal transducer (Aloka 210; Corometrics Medical Systems, Wallingford, CT, USA). A follicular wave had commenced in all cows by day 8 , and measurements of follicular growth continued until the fate of the first postpartum follicular wave had been determined. 


\section{Plasma measurements}

Plasma was collected and stored at $-20^{\circ} \mathrm{C}$ four times daily during days 8 and 9 (baseline period) and every hour during the 4-day infusion period. The samples were subsequently assayed for insulin, estradiol, testosterone, IGF-I, free IGF-I, IGF-binding proteins (IGFBP) and NEFA. Insulin concentrations were quantified daily on days 8 and 9 and every $2 \mathrm{~h}$ during the 96-h infusion period by a double-antibody radioimmunoassay (RIA; Linco Research, St Louis, MO, USA), with a sensitivity of $0.05 \mathrm{ng} / \mathrm{ml}$, as previously described (McGuire et al. 1995). Plasma estradiol concentrations were quantified daily by RIA (Serono Maia, Cortlandt Manor, NY, USA) on days 8 and 9, and every $6 \mathrm{~h}$ during the infusion period, as described previously by Beam and Butler (1997), with the following exceptions: the amount of primary antibody added to each tube was $25 \mu \mathrm{l}$, the standard curve extended from 0.063 to $10 \mathrm{pg}$ estradiol/tube, and total binding of tracer was greater than $30 \%$. Plasma testosterone levels were determined using a commercially available kit (DSL Inc., Webster, TX, USA). Because the expected values in plasma were lower than the declared sensitivity of the assay $(0.05 \mathrm{ng} / \mathrm{ml})$, a larger aliquot of plasma $(500 \mu \mathrm{l})$ was extracted in $5 \mathrm{ml}$ of 2:1 benzene-hexane, the tubes were dried, the extract was reconstituted in $50 \mu \mathrm{l}$ of gel-PBS $\left(0.1 \%\right.$ gelatin, $0.14 \mathrm{M} \mathrm{NaCl}, 3.5 \mathrm{mM} \mathrm{NaH} \mathrm{PO}_{4} .1 \mathrm{H}_{2} \mathrm{O}$, $7 \mathrm{mM} \mathrm{Na}_{2} \mathrm{HPO}_{4}$ anhydrous, $3 \mathrm{mM} \mathrm{NaN}, \mathrm{pH} 7.1$ ), and the assay was conducted according to the kit instructions. $\mathrm{LH}$ concentrations were determined by RIA (sensitivity $=0.2$ $\mathrm{ng} / \mathrm{ml}$ ) on all samples taken during the frequent sampling periods using USDA-bLH-B-6 for iodination and standard, and rabbit antibovine LH (R\#16; a gift from R.B. Staigmiller), as previously described (Price et al. 1987). Pulses were identified as values that were greater than two standard deviations above the mean LH concentration, and had at least one adjacent elevated point. Pulse amplitude is reported as the peak $\mathrm{LH}$ pulse value minus the baseline LH concentration. Circulating levels of total IGF-I were determined during the baseline period, and at 0, 48 and $96 \mathrm{~h}$ in a single assay following ethanol:acetone:acetic acid (60:30:10) extraction, as described by Enright et al. (1989), and complete removal of all binding proteins was verified by Western ligand blot. Sensitivity of the assay was $12 \mathrm{ng} / \mathrm{ml}$, and primary antibody and IGF-I for iodination and standards were sourced as previously described (Butler et al. 2003). Circulating levels of free IGF-I were determined during the baseline period and at 0, 48 and $96 \mathrm{~h}$ relative to the start of infusion in a single assay, using a commercially available sandwich-type IRMA (sensitivity $=0.03 \mathrm{ng} / \mathrm{ml}$; DSL Inc.). The plasma IGFBP profile was determined by Western ligand blot with ${ }^{125}$ I-labeled IGF-I at 0, 48 and $96 \mathrm{~h}$, using two gels in a single run on a double-gel unit, and IGFBP-3 and IGFBP-2 were identified by molecular mass, as previously described (Butler et al. 2003). Plasma NEFA concentrations were quantified daily on days 8 and 9 , and every
$12 \mathrm{~h}$ during the infusion period by enzymatic assay (Wako Pure Chemical Industries, Osaka, Japan). Inter- and intraassay coefficients of variation were 11.3 and $4.4 \%, 12.5$ and $7.1 \%, 15.3$ and $4.0 \%$, and 5.4 and $4.8 \%$ for the estradiol, insulin, LH, and testosterone RIA respectively.

\section{Energy balance determination}

Energy balance (EB) was calculated daily from measurements of milk yield and dry matter intake, body weight (weekly measurement), milk-fat percentage (twice-weekly measurement) and the calculated $N_{\mid}$value of the diet (Beam \& Butler 1997). Daily net energy consumed $\left(\mathrm{NE}_{\text {consumed }}\right)$ was increased for the animals on the INS treatment by a variable amount depending on the infusion rate of glucose required to maintain euglycemia, and this increment in $\mathrm{NE}_{\text {consumed }}$ was calculated as described previously (Butler et al. 2003).

\section{Statistical analysis}

All data were analyzed using statistical software from SAS (SAS Institute, Cary, NC, USA). Baseline values for each variable measured were used for covariate adjustment. When appropriate, hormone, metabolite and production data were analyzed as repeated measures within cow using an autoregressive plus random effect covariance structure, as described by Littell et al. (1998). When the interaction between treatment and time was significant $(P<0.05)$, pair-wise comparisons of individual means were carried out with the Tukey-Kramer test. LH data were analyzed as follows: (i) within each cow using a paired $t$-test comparing values measured during BASE with values measured during START and END; and (ii) between treatments using one-way ANOVA.

\section{Results}

\section{Insulin and glucose}

The temporal profiles of plasma insulin and blood-glucose levels are presented in Fig. 1. During the infusion period, plasma insulin concentrations (means \pm S.E.M.) were elevated 2.6-fold in INS cows over values in CTL cows (0.73 \pm 0.026 vs $0.28 \pm 0.026 \mathrm{ng} / \mathrm{ml}$; treatment, $P<0.001$ ). Euglycemia was maintained in INS cows during the infusion period via infusion of exogenous glucose, resulting in blood glucose values that were not different from CTL cows. To maintain euglycemia, the glucose infusion started at a rate of $40 \mathrm{~g} / \mathrm{h}$, increased gradually over the first $72 \mathrm{~h}$, and remained stable at $97 \pm 0.5 \mathrm{~g} / \mathrm{h}$ for the final $24 \mathrm{~h}$.

\section{Ovarian steroids}

Circulating estradiol concentrations were elevated in INS compared with CTL cows during the infusion period (treatment by time, $P<0.01$; Fig. 2). There was no difference between treatments for the initial $30 \mathrm{~h}$, after which 
(a)

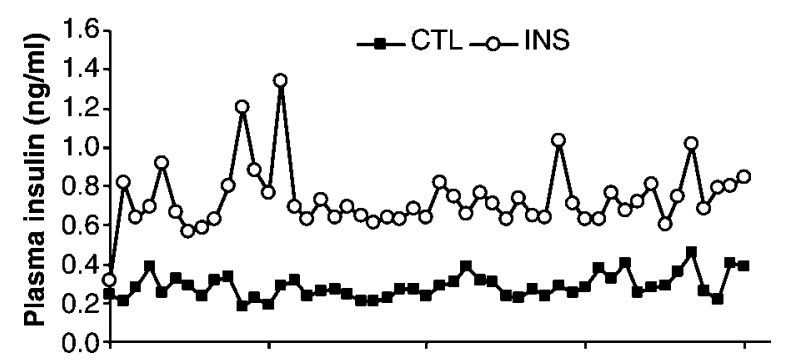

(b)

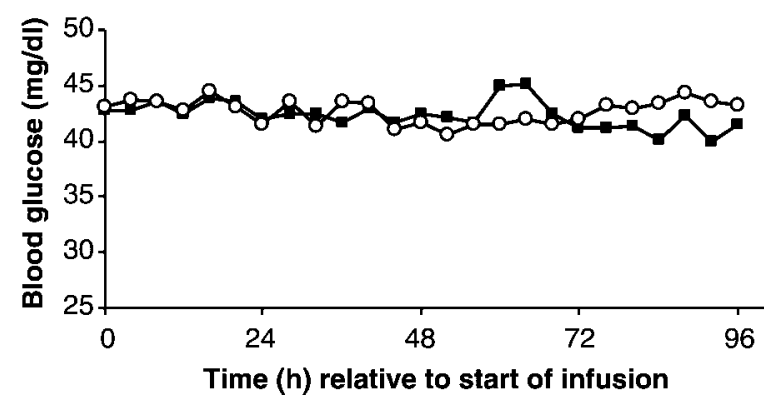

Figure 1 Mean plasma insulin and blood glucose concentrations in dairy cows during the infusion period. (a) INS cows were infused with insulin $(0.3 \mu \mathrm{g} / \mathrm{kg}$ body weight per h) at a constant rate commencing at $0 \mathrm{~h}$ and concluding at $96 \mathrm{~h}$, whereas CTL cows were infused with saline $(100 \mathrm{ml} / \mathrm{h})$. Plasma insulin levels were measured every $2 \mathrm{~h}$ during the infusion period. The insulin infusion resulted in increased $(P<0.001)$ circulating insulin (pooled S.E.M. $=0.026$ $\mathrm{ng} / \mathrm{ml}$ ). (b) Blood glucose was measured every hour during the infusion period in INS cows and every $4 \mathrm{~h}$ in CTL cows (4-h mean values were calculated for INS cows). Blood-glucose levels were not different between the treatments (pooled S.E.M. $=0.8 \mathrm{mg} / \mathrm{dl}$ ).

estradiol declined in the CTL cows, but increased and remained elevated in the INS cows. The plasma estradiol concentrations were significantly different by $48 \mathrm{~h}$, and this difference was essentially maintained for the remainder of the infusion period. A treatment by time interaction $(P=0.052)$ was also observed for plasma testosterone (Fig. 2). As with estradiol, there was no difference between treatments during the initial $30 \mathrm{~h}$, but circulating testosterone tended to be higher in the INS cows thereafter. The mean ratio of testosterone to estradiol was not different between treatments during the initial 30-h period $(15.7 \pm 2.8$ vs $15.3 \pm 3.2)$, but during the final $66 \mathrm{~h}$ of infusion, the mean ratio was significantly reduced in INS cows relative to CTL cows $(10.3 \pm 1.9$ vs $17.9 \pm 2.0$; $P<0.01)$.

\section{LH pulsatility}

The plasma LH pulse data is summarized in Table 1 . For the INS cows, no differences in LH pulse frequency, mean plasma $\mathrm{LH}$, baseline $\mathrm{LH}$, or pulse amplitude were detected either immediately after the start of infusion (START) or during the final stages of infusion (END) relative to values measured prior to the start of infusion (a)

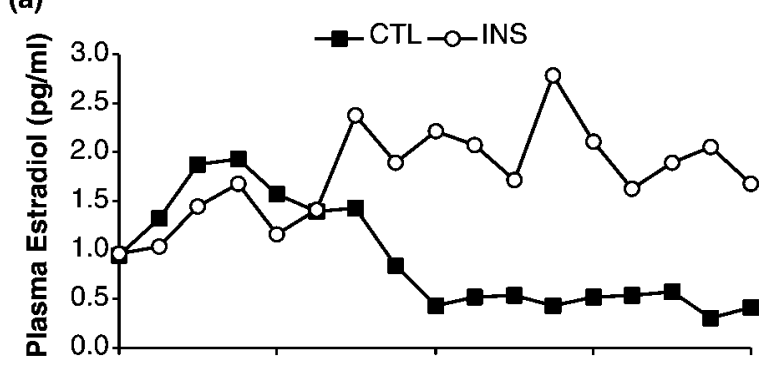

(b)

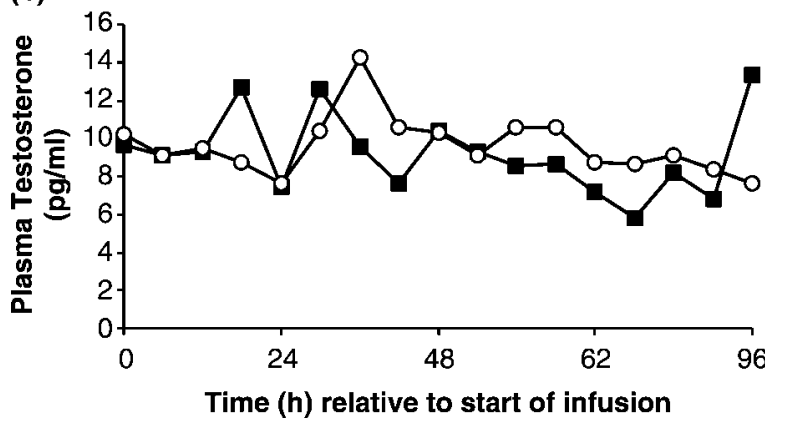

Figure 2 Mean plasma estradiol and testosterone in the INS and CTL cows during the 96-h infusion period. INS cows were infused with insulin $(0.3 \mu \mathrm{g} / \mathrm{kg}$ body weight per $\mathrm{h})$ at a constant rate from $0 \mathrm{~h}$ until $96 \mathrm{~h}$. CTL cows were infused with saline $(100 \mathrm{ml} / \mathrm{h})$. (a) Plasma estradiol was measured every $6 \mathrm{~h}$ during the infusion period (pooled S.E.M. $=0.48 \mathrm{pg} / \mathrm{ml}$ ). A significant treatment by time interaction $(P<0.01)$ was observed. (b) Plasma testosterone was measured every $6 \mathrm{~h}$ during the infusion period. A treatment by time interaction was observed ( $P=0.052$; pooled S.E.M. $=1.1 \mathrm{pg} / \mathrm{ml})$.

(BASE). There was a decline in the LH pulse frequency in the CTL cows from BASE to END during the infusion period (4.0 vs 2.4 pulses per $8 \mathrm{~h}$ in BASE vs END; S.E.M. $=0.6, P=0.056)$, but there was no change in the mean plasma $\mathrm{LH}$, baseline $\mathrm{LH}$ or pulse amplitude. No differences were observed between the treatments for any of the $\mathrm{LH}$ parameters measured $(P>0.2)$.

\section{Follicle growth}

The pattern of ovarian dominant follicle development in individual cows is illustrated in Fig. 3. Mean follicle diameter was slightly larger in INS cows throughout the infusion period, but this difference was significant $(P<0.05)$ only on day 10 at the time of the start of infusion. There were no significant effects of treatment $(P>0.1)$ or treatment by time $(P>0.1)$. No difference was observed between INS and CTL cows in cumulative dominant follicle growth between days 10 and $14(2.0 \pm 0.9$ vs $3.1 \pm 0.8 \mathrm{~mm} ; P>0.3)$. None of the dominant follicles of the first postpartum follicle wave ovulated or developed into cysts, and all ultimately became atretic.

\section{IGF-I, IGFBP and NEFA}

Circulating total IGF-I levels were not different between treatments at the beginning of the infusion period, and 
Table $1 \mathrm{LH}$ pulse data from the frequent blood samples collected prior to and during the infusion period.

\begin{tabular}{|c|c|c|c|c|c|c|c|c|c|c|c|}
\hline & \multicolumn{7}{|c|}{ Insulin treatment } & \multicolumn{4}{|c|}{ CTL treatment } \\
\hline & \multirow[b]{2}{*}{ BASE } & \multicolumn{3}{|c|}{ START } & \multicolumn{3}{|c|}{ END } & \multirow[b]{2}{*}{ BASE } & \multicolumn{3}{|c|}{ END } \\
\hline & & $\Delta$ & S.E.M. & $P$ & $\Delta$ & S.E.M. & $P$ & & $\Delta$ & S.E.M. & $P$ \\
\hline LH pulses (no./8 h) & 3.60 & 0.20 & 0.37 & 0.62 & 0 & 0 & 1 & 4 & -1.6 & 0.6 & 0.056 \\
\hline Mean LH (ng/ml) & 0.56 & -0.02 & 0.05 & 0.75 & 0.03 & 0.10 & 0.77 & 0.58 & -0.07 & 0.05 & 0.24 \\
\hline Base LH (ng/ml) & 0.38 & 0.01 & 0.03 & 0.62 & 0.03 & 0.03 & 0.40 & 0.38 & 0.005 & 0.02 & 0.85 \\
\hline Pulse amplitude (ng/ml) & 0.57 & -0.06 & 0.08 & 0.48 & 0.25 & 0.18 & 0.27 & 0.63 & -0.06 & 0.12 & 0.64 \\
\hline
\end{tabular}

BASE, START and END represent measurements taken during the $8 \mathrm{~h}$ period immediately prior to start of infusion, immediately after the start of infusion, and the final $8 \mathrm{~h}$ of infusion respectively. Treatment effects were examined as paired differences within individuals: START-BASE and END-BASE.

$\Delta=$ change relative to BASE.

remained constant in the CTL cows during the 96-h infusion period. Plasma total IGF-I concentration increased in response to insulin, and was $70 \%$ and $116 \%$ greater than values in CTL cows at 48 and $96 \mathrm{~h}$ respectively (treatment, $P<0.05$; treatment by time, $P<0.05$; Fig. 4). Circulating levels of free IGF-I were similar in both treatments at the start of the infusion period and remained constant in CTL cows during the infusion period, but increased in response to insulin (treatment, $P<0.05$; treatment by time, $P<0.05$; Fig. 4). At $48 \mathrm{~h}$, free IGF-I in INS cows was approximately double that in CTL cows $(P<0.01)$.

The temporal profile of circulating levels of IGFBP is shown in Table 2. No differences between treatments

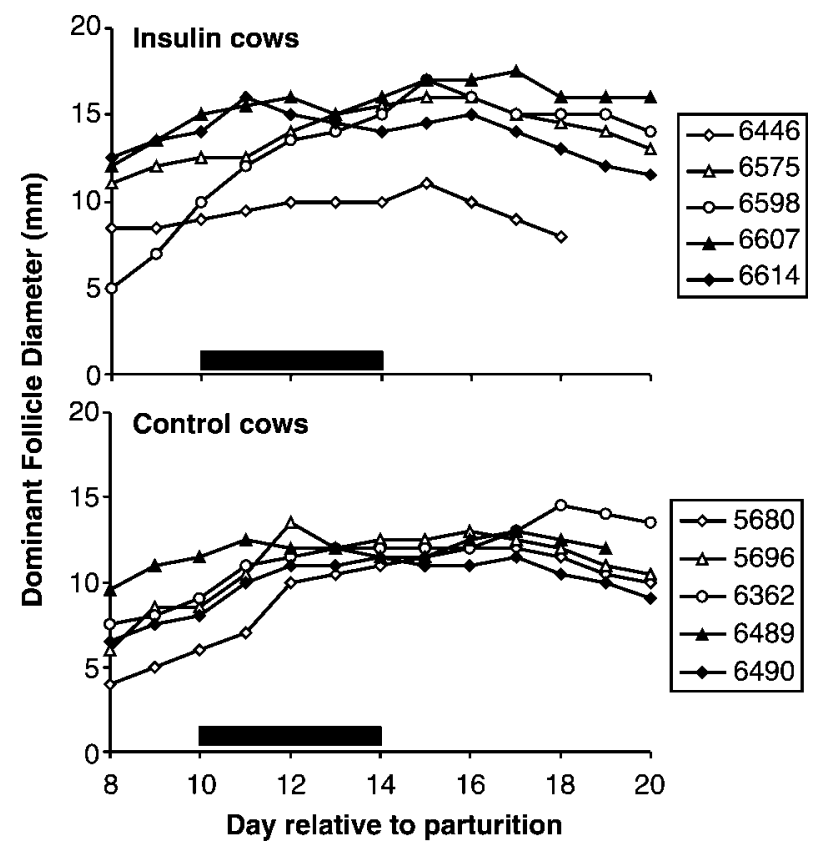

Figure 3 Individual temporal profiles of growth of the dominant follicle during the study period. INS cows (top) were infused with insulin $(0.3 \mu \mathrm{g} / \mathrm{kg}$ body weight per $\mathrm{h})$ and CTL (control) cows (bottom) were infused with saline $(100 \mathrm{ml} / \mathrm{h})$ for $96 \mathrm{~h}$ starting on day 10 postpartum. Follicles were measured by ultrasound once daily. Effects of treatment $(P>0.1)$ and treatment by time $(P>0.1)$ on mean follicle diameter were nonsignificant (pooled S.E.M. $=0.8 \mathrm{~mm}$ ). The solid black bar represents the infusion period. were observed for any of the binding proteins at $0 \mathrm{~h}$. Plasma IGFBP-3 (40-44 kDa doublet) was significantly increased in response to insulin (treatment, $P<0.05$; treatment by time, $P<0.07)$. Circulating levels of IGFBP$2(34 \mathrm{kDa})$ were reduced in response to insulin (treatment, $P<0.06$; treatment by time, $P<0.001$ ). Insulin treatment also resulted in a reduction in the $29 \mathrm{kDa}$ (treatment by time, $P<0.001$ ) and $24 \mathrm{kDa}$ binding proteins (treatment by time, $P<0.05)$.

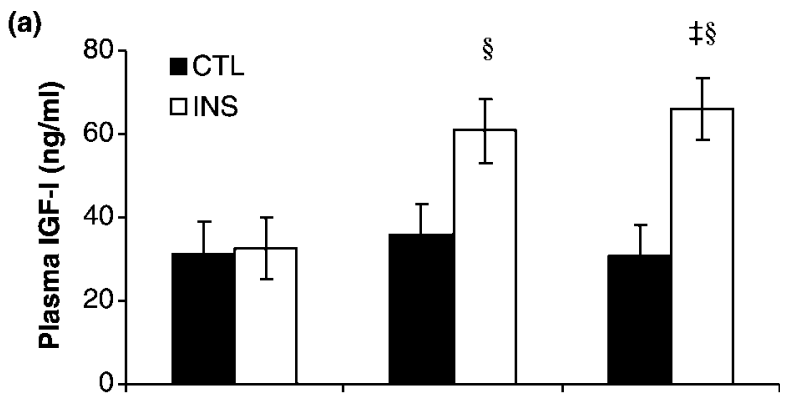

(b)

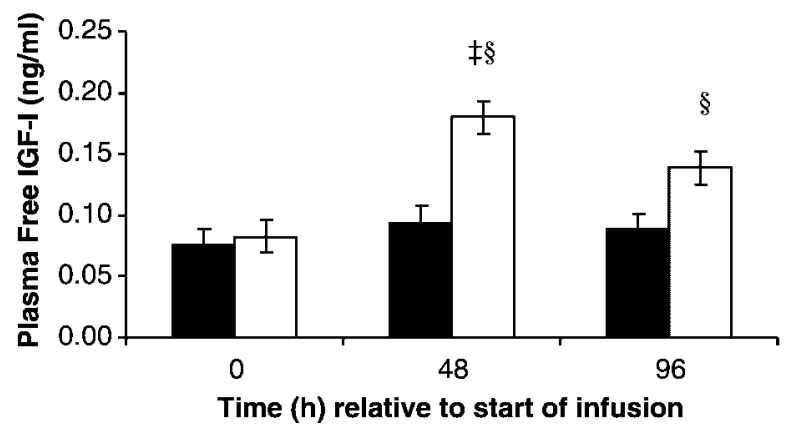

Figure 4 Plasma total and free IGF-I concentrations in INS and CTL cows during the 96-h infusion period. INS cows were infused with insulin $(0.3 \mu \mathrm{g} / \mathrm{kg}$ body weight per h), and CTL cows were infused with saline $(100 \mathrm{ml} / \mathrm{h})$. (a) Total IGF-I concentration in plasma was increased in response to insulin treatment (treatment, $P<0.05$; treatment by time, $P<0.05$ ). (b) The plasma concentration of free IGF-I was increased in response to insulin. Significant effects of treatment $(P<0.05)$ and treatment by time $(P<0.05)$ were observed. ${ }^{\ddagger}$ Treatments differed significantly $(P<0.05)$ at the specified time. ${ }^{\S}$ Within-treatment differences $(P<0.05)$ relative to $0 \mathrm{~h}$. 
Table 2 Changes in plasma insulin-like growth factor-binding proteins (IGFBP) in hyperinsulinemic-euglycemic clamp and saline-infused cows over the $96 \mathrm{~h}$ infusion period.

\begin{tabular}{|c|c|c|c|c|c|c|c|c|c|}
\hline & \multicolumn{3}{|c|}{ Insulin treatment } & \multicolumn{3}{|c|}{ CTL treatment } & \multirow[b]{2}{*}{ Pooled S.E.M. } & \multirow[b]{2}{*}{ TRT } & \multirow[b]{2}{*}{ TRT $\times$ time } \\
\hline & $\mathrm{Oh}$ & $48 \mathrm{~h}$ & $96 \mathrm{~h}$ & $\mathrm{Oh}$ & $48 \mathrm{~h}$ & $96 \mathrm{~h}$ & & & \\
\hline IGFBP-3 & 5224 & $6655^{\neq \S}$ & $6356^{\neq \S}$ & 4481 & 4956 & 4723 & 368 & 0.015 & 0.061 \\
\hline IGFBP-2 & 3722 & $1609^{\ddagger \S}$ & $742^{\neq \S}$ & 2881 & 3176 & 2499 & 315 & 0.054 & 0.001 \\
\hline 29 kDa & 396 & 297 & $195^{\S}$ & 298 & 335 & 289 & 38 & 0.8 & 0.001 \\
\hline $24 \mathrm{kDa}$ & 286 & 208 & $155^{\S}$ & 210 & 210 & 219 & 11 & 0.9 & 0.012 \\
\hline
\end{tabular}

Abundance of IGFBP is expressed in arbitrary densitometric units.

${ }^{\ddagger}$ Treatments differ at corresponding time points $(P<0.05)$.

${ }^{\S}$ Within-treatment differences compared to $0 \mathrm{~h}(P<0.05)$.

Circulating NEFA levels were reduced in response to insulin $(P<0.001$; data not shown). Over the duration of the infusion period, plasma NEFA levels in INS cows were reduced by $50 \%$ relative to values at $0 \mathrm{~h}$, whereas in $\mathrm{CTL}$ cows NEFA levels averaged $96 \%$ of the value at $0 \mathrm{~h}$.

\section{Production data}

Over the duration of the infusion period, average milk production $(39.3 \pm 0.6$ vs $41.1 \pm 0.6 \mathrm{~kg} /$ day; treatment, $P>0.05$; treatment by time, $P>0.5)$ and dry matter intake $(13.8 \pm 0.6$ vs $15.6 \pm 0.6 \mathrm{~kg} /$ day; $P>0.05$; treatment by time, $P>0.4$ ) were not different between INS and CTL cows respectively. Energy balance was not different between treatments at the beginning of the infusion period $(-17.9 \pm 2.6$ vs $-19.4 \pm 2.6 \mathrm{Mcal} /$ day; $P=0.7)$. During the $96-\mathrm{h}$ infusion period, energy balance was significantly improved in INS cows compared with CTL cows $(-11.1 \pm 2.6$ vs $-19.1 \pm 2.6 \mathrm{Mcal} /$ day; treatment, $P<0.05$; treatment by time, $P<0.05)$. The greatest difference was detected at the end of the infusion period $(-5.1 \pm 2.6$ vs $-18.9 \pm 2.6 \mathrm{Mcal} /$ day; $P<0.001)$.

\section{Discussion}

The most striking observation in this study was the sustained increase in circulating estradiol in response to insulin treatment in the absence of a change in $\mathrm{LH}$ pulsatility. Possible mechanisms to explain this observation are as follows: (i) insulin had a direct stimulatory effect on overall ovarian steroid production; (ii) insulin had a direct stimulatory effect specifically on aromatization of androgen to estrogen; (iii) insulin increased ovarian responsiveness to another circulating factor (such as $\mathrm{LH}$ or IGF-I); (iv) insulin had an indirect effect via altering circulating levels of another factor (such as NEFA or IGF-I).

Numerous reports from multiple species indicate that insulin has direct stimulatory effects on in vitro granulosa cell estradiol production, and indirect stimulatory effects via amplification of gonadotropin action (Poretsky \& Kalin 1987, Spicer \& Echternkamp 1995, Gutierrez et al. 1997, Poretsky et al. 1999, Silva \& Price 2002). However, reports demonstrating similar stimulatory effects in vivo are less abundant. This is probably due, at least in part, to insulininduced hypoglycemia when insulin is administered without cotreatment with glucose. The associated counterregulatory neuroendocrine responses to hypoglycemia may override any beneficial effects of insulin. Nevertheless, in beef cows, twice daily injections of insulin concomitant with a superovulation regimen resulted in a fivefold increase in estradiol concentration in large follicles and a twofold increase in the percentage of estrogen-active follicles compared with cows injected with saline (Simpson et al. 1994). Similarly, insulin administration to goats prior to or during a superovulation protocol resulted in a marked increase in follicular estradiol output (Selvaraju et al. 2003). Pigs treated with insulin for 2 days had increased ${ }^{125} \mathrm{I}$-hCG binding to granulosa cells, and increased follicular fluid content of estradiol and testosterone (Matamoros et al. 1990). Daily insulin administration to rats for 22 days significantly reduced the ratio of androstenedione to estrone (an indicator of aromatase activity; Poretsky et al. 1988). Similarly, in the current study, the ratio of testosterone to estradiol was reduced, indicating that aromatase activity was increased. Interestingly, in the study of Poretsky et al. (1988), specific ${ }^{125}$ Iinsulin binding to ovarian tissue homogenates was lower in insulin-treated than saline-treated rats, whereas specific ${ }^{125}$ I-labeled IGF-I binding was significantly increased. IGF-I and IGF-II are more potent than insulin at inducing $\mathrm{LH}$ receptors on granulosa cells and stimulating steroidogenesis (Davoren et al. 1986). Thus, insulin induced upregulation of type I IGF receptors would facilitate increased responsiveness to combined stimulation of ovarian steroidogenesis by IGF-I, IGF-II and insulin.

Circulating total and free IGF-I was increased in the current study in response to insulin infusion, and the attendant improvement in energy balance, in agreement with our previous findings using a higher insulin dose (Butler et al. 2003). In contrast to our earlier report, where an eightfold increase in insulin elevated circulating IGF-I by $400 \%$, we found that a more moderate 2.6 -fold increase in insulin required longer to stimulate higher circulating IGF-I, and the effect observed was more moderate $(116 \%$ increase). The latter, more modest increase in IGF-I would more closely resemble the slow rate of recovery in circulating IGF-I typically observed in postpartum dairy cattle. 
Of note, alterations in circulating IGFBP were only slightly reduced in the current study compared with the previous higher dose. It is likely that the shift in relative proportions of IGFBP-2 (decreased) and IGFBP-3 (increased), with half-lives of 30-90 min and $12-15$ h respectively (Jones \& Clemmons 1995), contributed to the increased circulating IGF-I in this study. The temporal profile of the alterations in free IGF-I are similar to our previous report (Butler et al. 2003). It is clear that increased IGF-I is beneficial to ovarian steroidogenesis, and thus may represent an important indirect means by which insulin increased estradiol synthesis.

Plasma NEFA is markedly elevated in dairy cows during early lactation, but glucose is the principal metabolic fuel of the ovary, and NEFA does not appear to be used in normal circumstances (Rabiee et al. 1997). Concentrations of NEFA in plasma and follicular fluid are closely related, and a negative relationship between follicular concentrations of NEFA and estradiol has been demonstrated (Comin et al. 2002, Jorritsma et al. 2003). Insulin action in target tissues is impaired by high circulating NEFA (Bajaj et al. 2002, Boden et al. 2002). Importantly, Glut4 - the insulinresponsive glucose transporter - is found in both granulosa and theca cells (Williams et al. 2001), indicating an important role for insulin in stimulating ovarian glucose uptake. During NEB, when both insulin and glucose are depressed and elevated NEFA is antagonistic to insulin action, ovarian activity may be suppressed due to inadequate uptake of oxidizable fuel. In addition, it has been demonstrated that the saturated fatty acids palmitate and stearate induce apoptosis in granulosa cells (Mu et al. 2001). In the current study, insulin-induced suppression of plasma NEFA may have removed inhibitory effects of NEFA.

An elegant study by Downing et al. (1999) on ewes with an autotransplanted ovary failed to indicate any positive effect of insulin on steroidogenesis or $\mathrm{LH}$ release. However, that report was different from the current study in a number of key aspects. Firstly, the insulin infusion lasted only $13.5 \mathrm{~h}$. In our study, we did not notice an effect of insulin on steroid production until beyond $30 \mathrm{~h}$ of infusion, implying that the positive effects of insulin are of a chronic rather than an acute nature. This would be in accordance with observations from others (Poretsky et al. 1988). Second, the infusions carried out with the autotransplanted ovary specifically affect the local arterial and venous system associated with ovarian tissue, with minimal effects on the peripheral concentrations of insulin. Thus, if an insulin-induced alteration of another factor (such as IGF-I or NEFA) is involved in increasing ovarian steroid output, the closed arterial infusion would not allow such an effect to be observed. Third, the cows in our study were experiencing the most severe period of NEB encountered during a gestation-lactation cycle; consequently, insulin levels were at their lowest when the infusions were carried out. Positive effects of insulin in vivo may not be observed above some threshold circulating level.
It is also possible that insulin itself acted as a survival signal for follicles that were otherwise destined to undergo atresia at an earlier time, as occurred in the saline-treated cows. Both insulin and IGF-I directly suppress apoptosis in rat preovulatory follicles (Chun et al. 1994). Treating pigs twice daily with insulin injections reduced the number and percentage of atretic follicles (Matamoros et al. 1990). In diabetic gilts, withdrawal of insulin therapy results in a significant increase in atretic follicles when compared with insulin-treated or nondiabetic gilts (Edwards et al. 1996).

It has recently been demonstrated that central actions of insulin are necessary for GnRH synthesis and/or secretion in mice (Brüning et al. 2000). Studies in sheep have indicated that dietary supplementation with lupin grain (a highly digestible energy and protein source) stimulates gonadotropin release. The increase in $\mathrm{LH}$ pulse frequency is associated with increased circulating and cerebrospinal fluid concentrations of insulin (Miller et al. 1998), and intracerebroventricular infusion of insulin to rams on a maintenance diet mimicked the effect of the lupin grain supplement (Miller et al. 1995). These results clearly imply that insulin is involved in the increase in LH pulse frequency in the wake of improved nutritional status in sheep. We found no evidence to indicate that a chronic elevation in circulating insulin during early lactation has a beneficial effect on LH pulsatility in dairy cows. In agreement with our findings, comprehensive studies in macaques (Schreihofer et al. 1996, Williams et al. 1996) indicate that the depressed plasma insulin and glucose encountered during undernutrition are not responsible for the reduced LH pulsatility. Those authors found that nutrient intake per se, rather than circulating concentrations of glucose or insulin, plays the principal role in restoring $\mathrm{LH}$ pulsatility following undernutrition. However, the status of the early-lactation dairy cow is different from fasting or undernutrition insofar as intake is actually increasing, but energy balance remains negative for an extended period due to the energetic costs of rising milk production. There is evidence to indicate that a lingering effect of pregnancy acts to restrain $\mathrm{GnRH} / \mathrm{LH}$ release regardless of energy balance status in early lactation (Canfield \& Butler 1991). Further work is necessary to characterize the causal agents(s) responsible for the suboptimal $\mathrm{GnRH} / \mathrm{LH}$ release during early postpartum NEB in the cow.

In conclusion, this study demonstrated that a chronic increase in circulating insulin during lactation-induced NEB results in reduced circulating NEFA, and increased circulating concentrations of both total and free IGF-I in conjunction with a shift from low MW IGFBP to the ternary complex. This altered metabolic environment during the first postpartum follicular wave resulted in increased circulating estradiol associated with a reduced ratio of testosterone to estradiol, indicating that aromatase activity was increased. This increase in circulating estradiol occurred independently of any change in LH pulsatility, 
implying that hypoinsulinemia is not responsible for the reduced $\mathrm{LH}$ pulse frequency observed in early lactation.

\section{Acknowledgements}

Partial support of this study was provided by funds allocated to US Department of Agriculture regional project NE-161. Technical advice from D.E. Bauman and D.A. Dwyer and assistance from W. English and B. Berggren-Thomas are greatly appreciated. Antisera to human IGF-I were obtained through NHPP, NIDDK and Dr A.F. Parlow. Antisera to bovine LH was a generous gift from R.B. Staigmiller. S.T. Butler was the recipient of a Walsh fellowship from Teagasc (Irish Agriculture and Food Development Authority) in support of his PhD program.

\section{References}

Arias P, Rodriguez M, Szwarcfarb B, Sinay IR \& Moguilevsky JA 1992 Effect of insulin on LHRH release by perifused hypothalamic fragments. Neuroendocrinology 56 415-418.

Bajaj M, Berria R, Pratipanawatr T, Kashyap S, Pratipanawatr W, Belfort R, Cusi K, Mandarino L \& DeFronzo RA 2002 Free fatty acid-induced peripheral insulin resistance augments splanchnic glucose uptake in healthy humans. American Journal of Physiology 283 E346-E352.

Beam SW \& Butler WR 1997 Energy balance and ovarian follicle development prior to the first ovulation postpartum in dairy cows receiving three levels of dietary fat. Biology of Reproduction $\mathbf{5 6}$ 133-142.

Beam SW \& Butler WR 1998 Energy balance, metabolic hormones, and early postpartum follicular development in dairy cows fed prilled lipid. Journal of Dairy Science 81 121-131.

Beam SW \& Butler WR 1999 Effects of energy balance on follicular development and first ovulation in postpartum dairy cows. Journal of Reproduction and Fertility Supplement 54 411-424.

Boden G, Cheung P, Stein TP, Kresge K \& Mozzoli M 2002 FFA cause hepatic insulin resistance by inhibiting insulin suppression of glycogenolysis. American Journal of Physiology 283 E12-E19.

Brüning JC, Gautam D, Burks DJ, Gillette J, Schubert M, Orban PC, Klein R, Krone W, Müller-Wieland D \& Kahn CR 2000 Role of brain insulin receptor in control of body weight and reproduction. Science $2892122-2125$.

Bucholtz DC, Chiesa A, Pappano WN, Nagatani S, Tsukamura H, Maeda KI \& Foster DL 2000 Regulation of pulsatile luteinizing hormone secretion by insulin in the diabetic male lamb. Biology of Reproduction 62 1248-1255.

Butler ST, Marr AL, Pelton SH, Radcliff RP, Lucy MC \& Butler WR 2003 Insulin restores GH responsiveness during lactation-induced negative energy balance in dairy cattle: effects on expression of IGF-I and GH receptor 1A. Journal of Endocrinology 176 205-217.

Butler WR 2003 Energy balance relationships with follicular development, ovulation and fertility in postpartum dairy cows. Livestock Production Science 83 211-218.

Butler WR \& Smith RD 1989 Interrelationships between energy balance and postpartum reproductive function in dairy cattle. Journal of Dairy Science 72 767-783.

Canfield RW \& Butler WR 1991 Energy balance, first ovulation and the effects of naloxone on LH secretion in early postpartum dairy cows. Journal of Animal Science 69 740-746.

Chilliard Y, Ferlay A, Faulconnier Y, Bonnet M, Rouel J \& Bocquier F 2000 Adipose tissue metabolism and its role in adaptations to undernutrition in ruminants. Proceedings of the Nutrition Society 59 127-134.
Chun SY, Billig H, Tilly JL, Furuta I, Tsafriri A \& Hsueh AJ 1994 Gonadotropin suppression of apoptosis in cultured preovulatory follicles: mediatory role of endogenous insulin-like growth factor I. Endocrinology 135 1845-1853.

Comin A, Gerin D, Cappa A, Marchi V, Renaville R, Motta M, Fazzini U \& Prandi A 2002 The effect of an acute energy deficit on the hormone profile of dominant follicles in dairy cows. Theriogenology 58 899-910.

Darwash AO, Lamming GE \& Woolliams JA 1997 The phenotypic association between the interval to post-partum ovulation and traditional measures of fertility in dairy cattle. Animal Science $\mathbf{6 5}$ 9-16.

Darwash AO, Lamming GE \& Woolliams JA 1999 The potential for identifying heritable endocrine parameters associated with fertility in post-partum dairy cows. Animal Science 68 333-347.

Davoren JB, Kasson BG, Li CH \& Hsueh AJ 1986 Specific insulin-like growth factor (IGF) I- and II-binding sites on rat granulosa cells: relation to IGF action. Endocrinology 119 2155-2162.

Diskin MG, Mackey DR, Roche JF \& Sreenan JM 2003 Effects of nutrition and metabolic status on circulating hormones and ovarian follicle development in cattle. Animal Reproduction Science $78345-370$.

Downing JA, Joss J \& Scaramuzzi RJ 1999 The effect of a direct arterial infusion of insulin and glucose on the ovarian secretion rates of androstenedione and oestradiol in ewes with an autotransplanted ovary. Journal of Endocrinology $163531-541$.

Edwards JL, Hughey TC, Moore AB \& Cox NM 1996 Depletion of insulin in streptozocin-induced-diabetic pigs alters estradiol, insulin-like growth factor (IGF)-I and IGF binding proteins in cultured ovarian follicles. Biology of Reproduction 55 775-781.

Enright WJ, Chapin LT, Moseley WM, Zinn SA, Kamdar MB, Krabill LF \& Tucker HA 1989 Effects of infusions of various doses of bovine growth hormone-releasing factor on blood hormones and metabolites in lactating Holstein cows. Journal of Endocrinology $122671-679$.

Gong JG, Lee WJ, Garnsworthy PC \& Webb R 2002 The effect of dietary induced increases in circulating insulin concentrations during the early postpartum period on reproductive function in dairy cows. Reproduction 123 419-427.

Gutierrez CG, Campbell BK \& Webb R 1997 Development of a long-term bovine granulosa cell culture system: induction and maintenance of estradiol production, response to follicle-stimulating hormone, and morphological characteristics. Biology of Reproduction 56 608-616.

van Houten M, Posner BI, Kopriwa BM \& Brawer JR 1979 Insulinbinding sites in the rat brain: in vivo localization to the circumventricular organs by quantitative radioautography. Endocrinology 105 666-673.

I'Anson H, Foster DL, Foxcroft GR \& Booth PJ 1991 Nutrition and reproduction. Oxford Reviews of Reproductive Biology 13 $239-311$.

Ingvartsen KL \& Andersen JB 2000 Integration of metabolism and intake regulation: a review focusing on periparturient animals. Journal of Dairy Science 83 1573-1597.

Jones JI \& Clemmons DR 1995 Insulin-like growth factors and their binding proteins: biological actions. Endocrine Reviews 16 $3-34$.

Jorritsma R, Groot MW, Vos PL, Kruip TA, Wensing T \& Noordhuizen JP 2003 Acute fasting in heifers as a model for assessing the relationship between plasma and follicular fluid NEFA concentrations. Theriogenology $60151-161$.

Kirchick HJ, Keyes PL \& Frye BE 1982 Restoration of the LH surge and ovulation by insulin in alloxan-diabetic immature rats treated with pregnant mare's serum gonadotrophin. Acta Endocrinologica $100266-273$.

Littell RC, Henry PR \& Ammerman CB 1998 Statistical analysis of repeated measures data using SAS procedures. Journal of Animal Science 76 1216-1231. 
Mamluk R, Greber Y \& Meidan R 1999 Hormonal regulation of messenger ribonucleic acid expression for steroidogenic factor-1, steroidogenic acute regulatory protein, and cytochrome P450 side-chain cleavage in bovine luteal cells. Biology of Reproduction 60 628-634.

Matamoros IA, Cox NM \& Moore AB 1990 Exogenous insulin and additional energy affect follicular distribution, follicular steroid concentrations, and granulosa cell human chorionic gonadotropin binding in swine. Biology of Reproduction 43 1-7.

McGuire MA, Bauman DE, Dwyer DA \& Cohick WS 1995 Nutritional modulation of the somatotropin/insulin-like growth factor system: response to feed deprivation in lactating cows. Journal of Nutrition 125 493-502.

Miller DW, Blache D \& Martin GB 1995 The role of intracerebral insulin in the effect of nutrition on gonadotrophin secretion in mature male sheep. Journal of Endocrinology 147 321-329.

Miller DW, Blache D, Boukhliq R, Curlewis JD \& Martin GB 1998 Central metabolic messengers and the effects of nutrition on gonadotrophin secretion in sheep. Journal of Reproduction and Fertility 112 347-356.

Mu YM, Yanase T, Nishi Y, Tanaka A, Saito M, Jin CH, Mukasa C, Okabe T, Nomura M, Goto K \& Nawata H 2001 Saturated FFAs, palmitic acid and stearic acid, induce apoptosis in human granulosa cells. Endocrinology 142 3590-3597.

Poretsky L \& Kalin MF 1987 The gonadotropic function of insulin. Endocrine Reviews 8 132-141.

Poretsky L, Glover B, Laumas V, Kalin M \& Dunaif A 1988 The effects of experimental hyperinsulinemia on steroid secretion, ovarian $\left[{ }^{125} I\right]$ insulin binding, and ovarian $\left[{ }^{125} I\right]$ insulin-like growth-factor I binding in the rat. Endocrinology 122 581-585.

Poretsky L, Cataldo NA, Rosenwaks Z \& Giudice IC 1999 The insulin-related ovarian regulatory system in health and disease. Endocrine Reviews 20 535-582.

Price CA, Morris BA \& Webb R 1987 Reproductive and endocrine effects of active immunization against a testosterone conjugate in the heifer. Journal of Reproduction and Fertility 81 149-160.

Rabiee AR, Lean IJ, Gooden JM, Miller BG \& Scaramuzzi RJ 1997 An evaluation of transovarian uptake of metabolites using arteriovenous difference methods in dairy cattle. Animal Reproduction Science 48 9-25.

Schreihofer DA, Renda F \& Cameron JL 1996 Feeding-induced stimulation of luteinizing hormone secretion in male rhesus monkeys is not dependent on a rise in blood glucose concentration. Endocrinology 137 3770-3776.

Schwartz MW, Woods SC, Porte D Jr, Seeley RJ \& Baskin DG 2000 Central nervous system control of food intake. Nature $\mathbf{4 0 4}$ 661-671.

Selvaraju S, Agarwal SK, Karche SD \& Majumdar AC 2003 Ovarian response, embryo production and hormonal profile in superovulated goats treated with insulin. Theriogenology 59 1459-1468.

Silva JM \& Price CA 2002 Insulin and IGF-I are necessary for FSHinduced cytochrome P450 aromatase but not cytochrome P450 side-chain cleavage gene expression in oestrogenic bovine granulosa cells in vitro. Journal of Endocrinology 174 499-507.

Simpson RB, Chase CC Jr, Spicer LJ, Vernon RK, Hammond AC \& Rae DO 1994 Effect of exogenous insulin on plasma and follicular insulin-like growth factor I, insulin-like growth factor binding protein activity, follicular oestradiol and progesterone, and follicular growth in superovulated Angus and Brahman cows. Journal of Reproduction and Fertility 102 483-492.

Spicer LJ \& Echternkamp SE 1995 The ovarian insulin and insulinlike growth factor system with an emphasis on domestic animals. Domestic Animal Endocrinology 12 223-245.

Stewart RE, Spicer LJ, Hamilton TD \& Keefer BE 1995 Effects of insulin-like growth factor I and insulin on proliferation and on basal and luteinizing hormone-induced steroidogenesis of bovine thecal cells: involvement of glucose and receptors for insulin-like growth factor I and luteinizing hormone. Journal of Animal Science 73 $3719-3731$.

Westwood CT, Lean IJ \& Garvin JK 2002 Factors influencing fertility of Holstein dairy cows: a multivariate description. Journal of Dairy Science 85 3225-3237.

Williams NI, Lancas MJ \& Cameron JL 1996 Stimulation of luteinizing hormone secretion by food intake: evidence against a role for insulin. Endocrinology 137 2565-2571.

Williams SA, Blache D, Martin GB, Foot R, Blackberry MA \& Scaramuzzi RJ 2001 Effect of nutritional supplementation on quantities of glucose transporters 1 and 4 in sheep granulosa and theca cells. Reproduction 122 947-956.

Received 6 November 2003

First decision 20 January 2004

Accepted 12 February 2004 